\title{
Early yield of five cacao families at three locations in Puerto Rico',2
}

\author{
Héber Irizarry ${ }^{3}$ and Edmundo Rivera ${ }^{4}$
}

J. Agric. Univ. P.R. 82(8-4):168-171 (1998)

\begin{abstract}
Five familles of Theobroma cacao $L$. between three and eleven years of age were evaluated for yleld at Gurabo, Corozal and Yabucoa. Parents involved in the combination of the familles were such well-known clones as 'Pound-7', 'Scavina (SCA)-6', 'Scavina-12', and IMC, EET and UF selectlons which have been widely used to produce controlled-pollinated seed in Central America and elsewhere. Elght months after transplant, the temporary shade provided by plantains was removed, and the trees were grown under full sunlight and intensive management. Between 1986 and 1993 individual tree yleld data were obtalned. In September 1989, hurricane Hugo destroyed the Yabucoa experiment but the evaluation continued at Gurabo and Corozal untll December 1993. At the termination of the first four-year evaluation period (1988 to 1989), families EET-400 $\times$ SCA-12 and SCA-6 $\times$ EET-62 were significantly superior yielders at Gurabo with an average total production of $5,538 \mathrm{~kg} / \mathrm{ha}$ of dry beans. None of the familles maintained superlority at Corozal and Yabucoa. The average total yield for all familles was 5,950 and $5,225 \mathrm{~kg} / \mathrm{ha}$ at Corozal and Yabucoa, respectlvely. The individual tree yield data showed that regardless of location only 2 or $3 \%$ of the trees within a family were high yielders and accounted for more than $60 \%$ of the total family production. At the termination of the eight-year evaluation perlod (19861993), families EET-400 $\times$ SCA-12 and SCA-6 $\times$ EET-62 maintained their superior yielding ablitity at Gurabo, with an average total production of 14,368 $\mathrm{kg} / \mathrm{ha}$. All familles performed similariy at Corozal with an average total production of $14,930 \mathrm{~kg} / \mathrm{ha}$.
\end{abstract}

Keywords: cacao, genotype, location, Theobroma cacao.

\section{RESUMEN}

Rendimiento temprano de cinco famillas de cacao en tres localldades de Puerto Rico

Se evaluó el rendimiento de cinco famillas de Theobroma cacao, L., de entre tres y once años de edad, en Gurabo, Corozal y Yabucoa. Los padres representados en estas famillas fueron los clones 'Pound-7', 'Scavina-6',

Manuscript submitted to Editorial Board 11 September 1995.

This paper covers work carried out cooperatively between the Agricultural Research Service-USDA and the Agricultural Experiment Station, University of Puerto Rico (AES-UPR), Río Piedras, Puerto Rico. The authors are grateful to Nicolás Díaz and Javier Fuentes, Agricultural Research Technicians, for their assistance in carrying out the experiments.

'Research Horticulturist, Tropical Agriculture Research Station, P.O. Box 70, Mayagiez, Puerto Rico 00681.

4Agronomist, Tropical Agriculture Research Station. 
'Scavina-12' y las selecciones IMC, EET y UF, todos extensamente utilizados en la producción de semilla bl-clonal en Centro América y otros lugares. A partir de ocho meses después del trasplante se removió la sombra temporera de plátanos y los árboles crecleron a pleno sol con manejo intensivo en parcelas replicadas. Entre el 1986 y 1993 se recopilaron datos del número de mazorcas y del peso seco de las almendras por árbol. En septiembre de 1989, el huracán Hugo destruyó el experimento de Yabucoa pero la evaluación continuó en Gurabo y Corozal hasta diclembre de 1993. A la terminaclón de los primeros cuatro afios de evaluación (1986-1989) las tamillas EET-400 x SCA-12 y SCA-6 $\times$ EET-62 tuvleron una producción significatlvamente mayor en Gurabo, con un rendimiento total por famllia de $5,538 \mathrm{~kg} / \mathrm{ha}$ de almendras secas. Ninguna de las famillas mantuvo superloridad en las localidades de Corozal y Yabucoa. El rendimlento medio para todas las famlllas fue de 5,950 y 5,225 $\mathrm{kg} / \mathrm{ha}$ en Corozal y Yabucoa, respectivamente. Los datos de rendimlento recopllados por árbol demostraron que Irrespectivo de la localidad, solamente el $203 \%$ de los árboles en cada familia eran altos productores y fueron responsables del $60 \%$ o más del rendimiento total de las famillas. A la terminación del período de evaluación de ocho años (19861993) las famillas EET-400 $\times$ SCA-12 y SCA-6 $\times$ EET-62 mantuvleron su alto potencial de producción en Gurabo con un rendimiento total por familia de $14,368 \mathrm{~kg} / \mathrm{ha}$. Todas las famillas se comportaron más o menos igual en Corozal, con un rendimiento medio de $14,930 \mathrm{~kg} / \mathrm{ha}$.

\section{INTRODUCTION}

Puerto Rico does not produce cacao on a commercial scale but possesses the soils and climate, and the availability of local and export markets that justify the agronomic evaluation of the crop. There are about 240,000 hectares of upland Ultisols and Oxisols, and 10,000 hectares of Inceptisols in the east-central humid valleys (Vicente-Chandler, 1985) either idle or underutilized that may be used for cacao production.

Local consumption of semi-processed cacao and confectionery chocolate is about 15,450 metric tons per annum with a value of $\$ 34$ million (PR Planning Board, 1988). In addition, Puerto Rico has unlimited access to the U.S. market that yearly imports about 1.7 million metric tons of dry beans (U.S. Department of Agriculture, 1993).

Local cacao cultivation began in 1636; however, adverse weather conditions and the appearance of a disease of unknown etiology prevented further development of the crop (Bermejo-Garcia, 1970). Limited cacao research was conducted by the Federal Experiment Station in Mayagüez between 1903 and 1940. These activities were confined to the introduction and selection of superior clones, basic fermentation and drying studies, black pod disease rating, and the recording of individual tree yield data (U.S. Department of Agriculture, 1903-1940). Later research was expanded to include the establishment of the cacao germplasm collection (Fisher et al., 1967). Concurrently with these activities, a second attempt was made to establish commer- 
cial orchards, but the newly established plantations succumbed to pests.

The availability of controlled-pollinated seed during the late $1970 \mathrm{~s}$ provided another incentive to investigate the possibility of growing cacao on a commercial scale in Puerto Rico. In addition to being the easiest and cheapest form of planting material, controlled-pollinated seed combine pest and disease resistance from distant parental clones (Enríquez y Soria, 1984; Enriquez y Paredes, 1985), and have the capacity to yield three to four times more than ordinary open-pollinated seed (Esquivel y Soria, 1967). This paper reports on the yield performance of five cacao families grown at three locations in Puerto Rico.

\section{MATERIALS AND METHODS}

Three experiments were established 12 August 1982 through 31 Decomber 1993. Four-month-old seedlings of families UF- $668 \times$ Pound-7, IMC-67 $\times$ UF-613, EET-400 $\times$ SCA-12, SCA-6 $\times$ EET-62 and IMC-67 $\times$ SCA-12 were planted at Corozal and Gurabo substations and on a private farm in the municipality of Yabucoa. The controlled-pollinated seed was introduced from the CATIE (Costa Rica) Cacao Improvement Program. The resultant seedlings were expected to contain superior combining ability for higher yield and resistance to pests and diseases.

Five treatments (families) were arranged in a randomized complete block design with six replications at Yabucoa and eight replications at Corozal and Gurabo. Each plot contained twelve experimental trees, spaced 3.05 by $3.05 \mathrm{~m}$, about 1,075 trees per hectare.

The Corozal substation is located in the north-central upland region at an elevation of about $200 \mathrm{~m}$. Throughout the experiment, the mean annual rainfall was $1,840 \mathrm{~mm}$, with pan evaporation of $1,410 \mathrm{~mm}$. Average annual minimum and maximum temperatures were 19.2 and $30.0^{\circ} \mathrm{C}$, respectively. The soil, a Corozal clay, an Ultisol (clayey, mixed, isohyperthermic Aquic Haplohumults), contained $2 \mathrm{mg} / \mathrm{kg}$ of "available" P (Bray method 2), and had an exchangeable cation capacity of $10.9 \mathrm{cmol}(+) / \mathrm{kg}$ of soil. Before planting, the soil was plowed to a $25-\mathrm{cm}$ depth and limestone was incorporated at the rate of $5.6 \mathrm{t} / \mathrm{ha}$ to raise the $\mathrm{pH}$ to about 5.3. Yearly broadcast liming applications were made at the rate of $3.4 \mathrm{t} / \mathrm{ha}$ after the trees began full production.

The Gurabo substation is located in the east-central interior valley at an elevation of $50 \mathrm{~m}$. During the course of the experiment the mean annual rainfall was $1,700 \mathrm{~mm}$ and pan evaporation $1,678 \mathrm{~mm}$. Average annual minimum and maximum temperatures were 20.2 and $31.6^{\circ} \mathrm{C}$, respectively. The soil, a Mabí clay, an Inceptisol (fine, montmorillonitic, 
isohyperthermic Vertic Eutropepts), $\mathrm{pH} 6.5$, contained $5 \mathrm{mg} / \mathrm{kg}$ of $\mathrm{P}$, and had an exchangeable cation capacity of $33.5 \mathrm{cmol}(+) / \mathrm{kg}$ of soil.

The Yabucoa experiment was established in the Playita suburb at about sea level. Throughout the experiment, mean annual rainfall was $2,274 \mathrm{~mm}$ and pan evaporation $1,796 \mathrm{~mm}$. Average annual minimum and maximum temperatures were 21.4 and $30.2^{\circ} \mathrm{C}$, respectively. The soil is a Talante sandy clay loam, an Entisol (coarse-loamy over sandy or sandy-skeletal, mixed, acid, isohyperthermic Aeric Tropic Fluvaquents). The soil, $\mathrm{pH} 4.6$, contained $40 \mathrm{mg} / \mathrm{kg}$ of $\mathrm{P}$, and had a low exchangeable cation capacity of only $3.8 \mathrm{cmol}(+) / \mathrm{kg}$ of soil. At all sites, evaporation exceeded rainfall during the months of January, February, March, June and July.

The four-month-old seedlings were field transplanted under the partial shade of six-month-old plantains, spaced at 3.05 by $3.05 \mathrm{~m}$. The plantains were removed after the first-crop harvest, about 14 months after planting.

During the first two and a half years, each tree received a total of 2.1. $\mathrm{kg}$ of a 10-5-20-3 $\left(\mathrm{N}, \mathrm{P}_{2} \mathrm{O}_{5}, \mathrm{~K}_{2} \mathrm{O}, \mathrm{MgO}\right)$ fertilizer supplemented with a minor element mixture at the rate of $25.4 \mathrm{~kg} / \mathrm{t}$ of fertilizer. Once the trees began full production in 1986, the fertilizer rate was increased to $1.8 \mathrm{~kg} /$ year until 1989 . Thereafter the rate was increased to $2.7 \mathrm{~kg} / \mathrm{tree} /$ year. The total amount was divided into equal applications at threemonth intervals.

Every four months the tree trunk was drenched with a solution of Oxamyl (Vidate-L) ${ }^{4}$ at the rate of $10 \mathrm{ml} / 3.8 \mathrm{~L}$ of water to control Phyllophaga sp., so far the most tenacious cacao insect in Puerto Rico. This control measure was supplemented with applications of Aldicarb (Temik 10-G) at the rate of $28 \mathrm{~g} /$ tree every six months.

Weed growth was suppressed with a rotary mower and spot applications of either paraquat (Gramoxone) or glyphosate (Round-up), both at the rate of $1 \% \mathrm{v} / \mathrm{v}$. The trees were pruned to control vertical growth and to facilitate cultural practices.

Between 1986 and 1989, ripened pods were harvested from 1,320 trees. In September 1989, hurricane Hugo severely damaged the Yabucoa experiment, which was terminated three months later. The harvest from 960 trees continued at the Gurabo and Corozal experiments until December 1993. Therefore, data are presented for four years (19861989) at three locations, and for an additional four years at only two locations. The pods were opened and the wet beans extracted, fermented,

Trade names in this publication are used only to provide specific information. Mention of a trade name does not constitute a warranty of materials by the USDA/ARS or the AES/UPR, nor is this mention a statement of preference over other materials. 
TABLE 1.-Tbtal yield of five cacao families grown under full sunlight at three locations in Puerto Rico during a four-year evaluation period, 1986-1989.

\begin{tabular}{|c|c|c|c|}
\hline \multirow[b]{2}{*}{ Family } & \multicolumn{3}{|c|}{ Location and bean dry weight } \\
\hline & Gurabo & Corozal & Yabucoa \\
\hline & -........ & $--\mathrm{kg} / \mathrm{ha}--$ & $\ldots . . . . .$. \\
\hline EET-400 $\times$ SCA-12 & $5,770.4 \mathrm{a}^{1}$ & $6,427.0 \mathrm{a}$ & $5,108.6$ a \\
\hline SCA-6 $\times$ EET 62 & $5,306.6 \mathrm{a}$ & $5,959.3 \mathrm{a}$ & $4,965.7 \mathrm{a}$ \\
\hline UF-668 $\times$ Pound-7 & $5,140.2 \mathrm{ab}$ & $6,151.2 a$ & $5,537.6 a$ \\
\hline $\mathrm{MMC}-67 \times \mathrm{SCA}-12$ & $4,015.3 \mathrm{bc}$ & $5,574.4 \mathrm{a}$ & $5,291.0 \mathrm{a}$ \\
\hline IMC-67 x UE-618 & $3,682.6 \mathrm{c}$ & $5,638.3$ a & $5,227.7 \mathrm{a}$ \\
\hline
\end{tabular}

Means within a column followed by the same letter do not differ significantly at the 0.05 probability level.

and sundried to about 7\% moisture content. Since number of pods and bean dry weight are the most important traits that determine yield in cacao (Soria, 1966), data on both attributes were collected. The pod index (number of pods needed to produce $1 \mathrm{~kg}$ of dry beans) was determined, and both bean dry weight and pod index were submitted to an analysis of variance. Treatment means were compared by using Duncan's test of significance.

\section{RESULTS AND DISCUSSION}

The first meaningful cacao production was obtained in 1986, when the trees were about three and a half years old from seed. At this age, about $97 \%$ of the trees were in production at all locations.

TABLE 2.-Mean pod index values obtained in five cacao families grown under full sunlight at three locations in Puerto Rico during a fouryear evaluation period, 1986-1989.

\begin{tabular}{|c|c|c|c|}
\hline \multirow[b]{2}{*}{ Family } & \multicolumn{3}{|c|}{ Location } \\
\hline & Gurabo & Corozal & Yabucoa \\
\hline $\mathrm{MMC}-67 \times \mathrm{SCA}-12$ & $72.1 \mathrm{a}^{1}$ & $71.6 \mathrm{a}$ & $79.2 \mathrm{a}$ \\
\hline IMC-67 × UF-613 & $65.5 \mathrm{ab}$ & $66.2 \mathrm{ab}$ & $67.0 \mathrm{a}$ \\
\hline UF-668 $\times$ Pound-7 & 60.8 bc & $62.2 \mathrm{bc}$ & $59.8 \mathrm{~b}$ \\
\hline EET-400 $\times$ SCA-12 & $54.6 \mathrm{c}$ & $56.5 \mathrm{c}$ & $56.9 \mathrm{~b}$ \\
\hline SCA-6 $\times$ EETT-62 & $37.4 \mathrm{~d}$ & $39.7 \mathrm{~d}$ & $37.6 \mathrm{c}$ \\
\hline
\end{tabular}

'Means within a column followed by the same letter do not differ significantly at the 0.05 probability level. 
There was no significant interaction between families and locations for bean dry weight and pod index (data not shown). However, the comparison among families within locations demonstrated that at the termination of the first four-year evaluation period, families EET-400 $x$ SCA-12 and SCA-6 $\times$ EET-62 were significantly superior yielders at Gurabo, with an average total production of $5,538 \mathrm{~kg} / \mathrm{ha}$ of dry beans (Table 1). There was no significant difference among families at Corozal and Yabucoa. The average total yield for all families was $5,940 \mathrm{~kg} / \mathrm{ha}$ at Corozal and $5,225 \mathrm{~kg} / \mathrm{ha}$ at Yabucoa.

Families EET-400 $\times$ SCA-12 and SCA-6 $\times$ EET-62, the highest yielders at Gurabo, also had a significantly lower pod index at all locations (Table 2). Likewise, the families that had the greatest pod index, IMC-

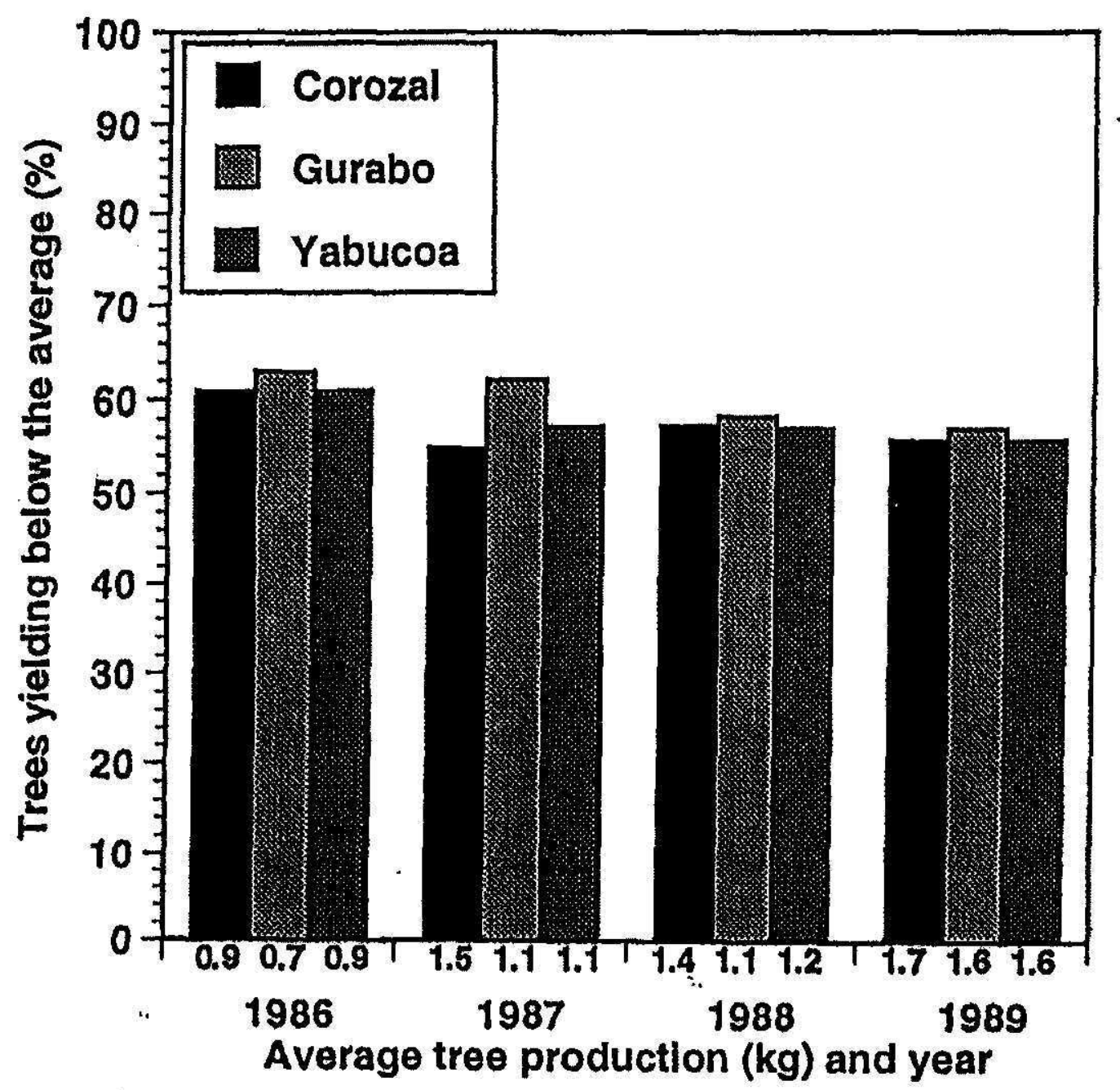

Fraume 1. Percentage of low yielding trees recorded in five cacao familieg at three locations in Puerto Rico during a four-year evaluation period, 1986-1989. 
$67 \times$ SCA-12 and IMC-67 $\times$ UF-613, also yielded significantly less at Gurabo. Since pod index is an indirect measurement of pod size (Soria, 1966), the largest individual pods were produced in the high yielding families. This finding may indicate that pod index rather than the number of pods is a more reliable criterion to determine yield in cacao. However, the significantly lower pod index detected in families EET$400 \times$ SCA-12 and SCA- 6 × EET-62 at Corozal and Yabucoa did not result in a significant increase in yield at these locations (Table 1).

The individual tree yield data obtained during the first four years of evaluation demonstrated that differences among trees within families were greater at all locations and fairly consistent from year to year (data not shown). In general, only 2 or $3 \%$ of high yielding trees within a family consistently accounted for more than $60 \%$ of the total family yield. This led to the selection of high yielding trees and the establishment of a clone-grafted evaluation experiment that is currently in progress. During the first full-production year (1986), about $61.7 \%$ of all trees at all locations yielded below the average (Figure 1). At the termination of the fourth full-production year (1989), about $56.2 \%$ of all trees in the five families and three locations continued yielding below the average of $1.6 \mathrm{~kg}$ of dry beans per tree. These results demonstrated that the high yielding ability attributed to controlled-pollinated seed in cacao is confined to only a few superior trees. Other investigators (Batista, 1981; Esquivel and Soria, 1967) have reported that in cacao families, only 8 to $14 \%$ of the population is composed of high yielding trees.

At the termination of the eight-year evaluation period, families EET-400 $\times$ SCA-12 and SCA-6 $\times$ EET-62 maintained their superior yielding ability at Gurabo, with an average total production of 14,368 $\mathrm{kg} / \mathrm{ha}$ of dry beans (Table 3). This yield was significantly higher, about

TABLE 3.--Total yield of five cacao families grown under full sunlight at two locations in Puerto Rico during an eight-year evaluation period, 1986-1993.

Location and bean dry weight

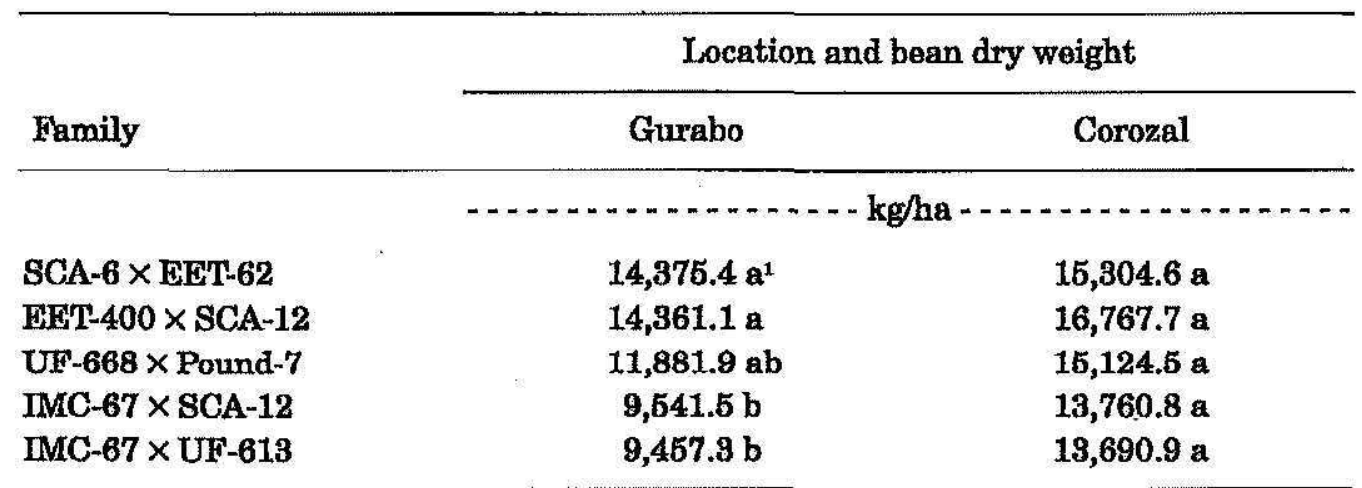

'Means within a column followed by the same letter do not differ significantly at 0.05 probability level. 
TABLE 4.-Mean pod index values obtained in five cacao families grown under full sunlight at two locations in Puerto Rico during an eight-year evaluation period, 1986-1993.

\begin{tabular}{lcl}
\hline & \multicolumn{2}{c}{ Location } \\
\cline { 2 - 3 } Family & Gurabo & Corozal \\
\hline IMC-67 $\times$ SCA-12 & $48.1 \mathrm{a}^{1}$ & $62.7 \mathrm{a}$ \\
IMC-67 $\times$ UF-613 & $46.2 \mathrm{ab}$ & $49.0 \mathrm{~b}$ \\
UF-668 $\times$ Pound-7 & $44.6 \mathrm{bc}$ & $48.0 \mathrm{bc}$ \\
EET-400 $\times$ SCA-12 & $42.9 \mathrm{c}$ & $45.1 \mathrm{c}$ \\
SCA-6 $\times$ EET-62 & $29.5 \mathrm{~d}$ & $32.2 \mathrm{~d}$
\end{tabular}

'Means within a column followed by the same letter do not differ significantly at 0.05 probability level.

$34 \%$ higher, than the production obtained from families IMC- $67 \times$ SCA12 and IMC-67 $\times$ UF-613. All families performed similarly with an average total production of $14,930 \mathrm{~kg} / \mathrm{ha}$ at Corozal (Table 3).

Throughout the duration of the experiments, families EET- $400 \times$ SCA-12 and SCA-6 $\times$ EET-62 also maintained a significantly lower pod index at Gurabo and Corozal (Table 4). However, only at Gurabo lower pod index resulted in a significant increase in yield (Table 3). At the termination of the last four-year evaluation period (1990-1993), all families at Gurabo and Corozal averaged about $60 \%$ more dry bean production and $25 \%$ reduction in pod index than in the first four years (1986-1989).

\section{LTTERATURE CITED}

Batista, B. J., 1981. Evaluación de la capacidad productiva de 6 hrbridos de cacao en la República Dominicana. Proc. $8^{\text {th }}$ Int. Cocoa Res, Conf, Cartagena, Colombia 713717.

Bermejo-García, J. G.,1970. Panorama histórico de la agricultura en Puerto Rico. Inst. Cultura Puertorriqueña, Escuela de Estudios Americanos, Sevilla.

Enriquez, G. A. y A. Paredes, 1985. El cultivo del cacao. Serie: Cultivos mayores No. 4, Editorial Univ. Estatal, San José, Costa Rica.

Enríquez, G. A. y J. V. Soria, 1984. Mejoramiento genético para resistencia a cinco enfermedades del cacao. Series: Material de ensenanza No. 9, CATIE, Turrialba, Costa Rica.

Esquivel, O. y J. V. Soria, 1967. Algunos datos sobre la variabilidad de algunos componentes del rendimlento en poblaciones de híbridos interclonales de cacao. Cacro, CATIE, Turrialba, Costa Rica 12(4):1-8.

Fisher, H. H., P. K. Soderholm and R. P. Kahn, 1967. U. S. Department of Agriculture cacao clone collection. Crops Regearch, ARS Bull. 34-37-4.

P. R. Planning Board, 1988. External trade statistics. Bureau of Economic Analysis, Santurce, P. R. 
J. Agric. Univ. P.R. vol. 82, NO.3-4, JULY-OCTOBER $1998 \quad \cdot 171$

Soria, J. V., 1966. Obtención de clones de cacao por el mótodo de índices de selección. Revista Turrialba, CATIE, Costa Rica 16(2):119-124.

U. \$. Department of Agriculture, 1993. Agricultural Statistics. U. S. Government Printing Office, Washington, D. C.

U. S. Department of Agriculture, 1903-1940. Annual reports. P.R. Agric. Exp. Sta., Mayaguez, P. R.

Vicente-Chandler, J., 1985. Una nueva agricultura para Puerto Rico-Año 2000. USDAARS, Agric. Exp. Sta. Univ. P.R. 